\title{
Erratum to: In Defence of the "Thin": Reflections on the Intersections Between Interactive Documentaries and Ethnography
}

\author{
Paolo S. H. Favero
}

\section{Erratum to:}

Chapter 5 in: E. Gómez Cruz et al. (eds.), Refiguring Techniques in Digital Visual Research, Digital Ethnography https://doi.org/10.1007/978-3-319-61222-5_5

The original version of this chapter was published with an error in the chapter author name, which should read as "Paolo S. H. Favero" in all the renditions. 